\title{
DĄŻENIE DO SENSU, CZYLI O POTRZEBIE KORZYSTANIA Z NAUK POMOCNICZYCH W LITERATUROZNAWSTWIE
}

\author{
Striving for a Meaning, that is, the Necessity to Use Ancillary Sciences \\ in Literary Studies
}

Keywords: language, literature, communication, espression, auxiliary science

Contact: Uniwersytet Śląskiw Katowicach; wrobelaleksandral@gmail.com

Nad rozróżnieniem nauki od wiedzy zastanawiano się już w starożytności. Arystoteles dokonał rozróżnienia na „episteme” (wiedzę) i „doxa” (opinię) a Platon uznał, że opinię można uzasadnić. W średniowieczu pojawiły się ,artes liberales” tzw. sztuki wyzwolone, które oddzielono od filozofii. Następnie podzielono je na „quadrivium” (algebrę, geometrię, astronomię i muzykę) oraz „trivium” (gramatykę, logikę i retorykę). Naukami praktycznymi poza rzemiosłem były również prawo i medycyna. W czasach nowożytnych zaczęto łączyć empiryzm i racjonalizm. Zdaniem Newtona każde stwierdzenie powinno zostać dobrze uzasadnione. W XVI w. najsilniej rozwijała się fizyka a w XIX w. biologia. Należy też podkreślić, że w XIX w. nastąpił również znaczny rozwój nauk humanistycznych i społecznych - szczególnie historia, archeologia, językoznawstwo, kulturoznawstwo itd. (Woleński 2009: 163-166). Oznacza to, że człowiek zawsze walczył o dostęp do wiedzy i usiłował ją usystematyzować. Zadaniem nauki jest poszukiwanie odpowiedzi na nurtujące pytania. Motywacją do podejmowania działania jest brak wiedzy, który jest likwidowany w wyniku poznania naukowego. Zatem uznać, że „wiedza jest bogactwem i dobrem ogólnym, które jest warunkiem rozwoju cywilizacji i do którego prawo ma każdy" (Podgórni 2013: 12).

Każda nauka posiada cele i wartości poznawcze, które realizuje się podczas badań naukowych. Celem nauki jest ,poszukiwanie dobrych wyjaśnień dla wszystkiego, co według nas potrzebuje i wyjaśnia” (Popper 1992: 252). Osiągnięcie wyznaczonego celu odbywa się przez realizowanie badań przy użyciu odpowiedniej metodologii. Nauka jest realizowana przez funkcje: edukacyjną, innowacyjną, emancypacyjną. To one stymulują osiągniecie celu badawczego (Strawiński 2011: 323). 
Każda nauka jest zbiorem wiedzy i nieustannie dąży się do jej ulepszania. Musi jednak zawsze opisywać istniejącą rzeczywistość, więc do jej opisu niezbędna jest komunikacja (przy użyciu języka, znaków) oraz metoda. Wyróżnia się pięć gatunków wiedzy ludzkiej, do których należy wiedza potoczna, naukowa, artystyczno-literacka, spekulatywna i irracjonalna (Such, Szczęśniak 2006: 37-44). W nauce należy rozróżnić dyscyplinę naukową od dziedziny naukowej. Pierwsze to działalność badawcza, której głównym celem jest zdobycie informacji. Istotne jest to, że jest ona wyodrębniona i umożliwia zdobycie stopnia oraz tytułu naukowego. W obrębie dyscypliny realizuje się specjalności naukowe, które badają jedynie uszczegółowiony wycinek rzeczywistości. Natomiast dziedziny nauki są tworzone w obrębie dyscyplin naukowych. Klasyfikacja dziedzin w Polsce odbywa się według Rozporządzenia Ministra Nauki i Szkolnictwa Wyższego z 25 września 2018 r. Na jej podstawie wyróżnia się osiem dziedzin naukowych, a w każdej z nich wymieniono dyscypliny naukowe lub artystyczne (Rozporządzenie Ministra Nauki i Szkolnictwa Wyższego Dz.U. 2018 poz. 1818) Językoznawstwo, które stanowi temat niniejszego opracowania zostało zaliczone do dziedzin nauk humanistycznych. Trzeba zaznaczyć, że powstanie nauki nie jest proste. Zbiór wiedzy nie zawsze zyskuje miano dziedziny naukowej, w obrębie której tworzy się specjalności. W celu odróżnienia dziedzin wiedzy od dziedzin nauki A. Comte stworzył specjalne kryteria pod postacią pytań:

1. Czy dana dziedzina wiedzy posiada swój własny, osobisty podmiot badań?

2. Czy dana dziedzina wiedzy posiada swój własny, osobisty przedmiot badań?

3. Czy dana dziedzina wiedzy posiada swoją własną terminologię?

4. Czy dana dziedzina wiedzy mieści się w podstawowych klasyfikacjach nauki?

Udzielenie odpowiedzi twierdzących na wszystkie pytania pozwalało stwierdzić, czy zbiór wiedzy może być zaliczany do dziedziny naukowej. Na podstawie tych pytań A. Comte w „Kursie filozofii pozytywnej” podzielił wszystkie dziedziny wiedzy ludzkiej na nawyki abstrakcyjne i konkretne. Usystematyzowanie dziedzin związanych z wiedzą o człowieku stało się punktem wyjścia do prowadzenia badań nad funkcjonowaniem człowieka w społeczeństwie. Na podstawie wymienionych pytań wiele zbiorów wiedzy można było zaliczyć do nauki, co budziło wiele wątpliwości wśród badaczy. Kontynuatorzy teorii A. Comte postanowili dodać pytanie, które brzmi: Czy dana dziedzina wiedzy posiada swoistą metodologię badań? Ewolucja działań nad badaniem dziedzin naukowych sprawiła, że praktycznie żadna nauka nie mogła poradzić sobie samodzielnie i wymagała stworzenia kategorii nauk pomocniczych lub współpracujących. Choć każda $\mathrm{z}$ nauk pomocniczych może funkcjonować samodzielnie, jako inna dziedzina wiedzy to zapożycza ona własne narzędzia na 
potrzeby wybranej dziedziny naukowej. Pomaga wyjaśnić trudne zjawiska - ukazując je $\mathrm{z}$ innej perspektywy.

Najogólniej językoznawstwo określa się, jako naukę o języku, która bada jego tendencje rozwojowe. Zakładając, że język jest narzędziem do porozumiewania się i ekspresji należałoby zastanowić się czy językoznawstwo potrzebuje nauk pomocniczych do sterowania rozwojem języka?

Język zmienia się nieustannie i wymaga ciągłego doskonalenia. Ulega trendom, i zapożyczeniom. Czasami pojawiają się w nim nowe słowa (neologizmy), regionalizmy a inne słowa i zwroty stają się przeżytkami, archaizmami oraz przemijają wraz z modą. Wpływ na to mają przemiany społeczno-gospodarcze, polityczne, kulturowe a także zjawisko migracji, globalizacji a nawet magdonaldyzacji. Językoznawstwo badana przemiany zachodzące w języku - jednak nie jest to możliwe bez szerszego kontekstu. Oznacza to, że dziedziny pomocnicze językoznawstwa przyczyniają się do zrozumienia języka i kierunków jego przemian. W efekcie językoznawstwo podzielono na dwa główne trendy. Pierwszy to językoznawstwo synchroniczne, które zajmuje się badaniem istniejącego stanu systemu językowego oraz jednostek. A drugie to językoznawstwo diachroniczne, które skupia się na rozwoju i historii języka. Pojawia się również lingwistyka porównawcza, gdzie porównuje się minimum dwa różne języki. Wśród dziedzin pomocniczych należy wymienić: socjologię, semiotykę, kulturoznawstwo, etnologię, antropologię, psychologię, historię, filozofię, prawo, pedagogikę, religioznawstwo i teologię, ale również medioznawstwo i ekonomię.

Zakładając, że język nie jest tylko po to, aby komunikować się z innymi lecz wyrażać również ekspresję należy posłużyć się naukami pomocniczymi. Przy użyciu języka możliwe jest wyrażenie własnej osobowości. Sam proces porozumiewania się ludzi jest złożony a akt komunikacji dopasowuje się do aktualnych wydarzeń. Nie można go uchwycić tak, aby odpowiadał każdej sytuacji komunikacyjnej. Wynika to z faktu, w którym każdy człowiek jest niepowtarzalnym uczestnikiem komunikacji. Pojawiają się jednostkowe schematy myślowe. Niewątpliwie człowiek jest ukształtowany przez odrębne treści, system wartości, środowisko zewnętrzne - w tym język. Należy także zaznaczyć, że sens współwystępowania nauk pomocniczych w językoznawstwie jest konieczny. Pojawiające się publikacje językoznawcze świadczą o tym, że wielu z nich ma pretensje o nieuwzględnianie potrzeb współczesnego społeczeństwa. O jakość języka dba się coraz mniej, szczególnie w przestrzeni internetu. Używanie skrótowców, zapożyczeń, idiomów, emotikomów i akronimów powoduje, że język coraz bardziej odchodzi od tradycji i rozwija się w przestrzeni medialnej. Kultura języka zanika i brakuje autorytetów, które trafiłyby do współczesnych młodych ludzi. Natomiast ci, którzy zwracają uwagę na poprawność języka i pojawiające się błędy - 
traktowani są w kategorii hejterów i dziwaków. Zatem potrzeba szerszego kontekstu, aby językoznawstwo stało się znów dziedziną dbającą o wspólne dobro i budowanie świadomości narodowej. Przykładowo zadaniem pedagogiki jest uczenie młodych ludzi podstaw języka oraz promowanie kultury językowej. Osiągnięcie poprawności językowej nie jest możliwe bez dobrej komunikacji oraz faktów społecznych i wzorów kultury. Potrzeba korzystania z nauk pomocniczych w językoznawstwie przybliża naukę społeczeństwu i zachęca ludzi do stosowania ogólnie przyjętych zasad. Każda z nauk pomocniczych wnosi nowy sens w przestrzeni językoznawstwa. Ludzie potrzebują różnych bodźców, które pomogą im w procesie komunikowania. Sensem jest wyjaśnienie trudnych pojęć i dążenie do osiągnięcia celu, który uważa się za pozytywny. To wszelkie czynności, które sprzyjają prawidłowemu myśleniu. W efekcie sens staje się pojęciem bliskoznacznym dla rozsądku. Dążenie do sensu w językoznawstwie sprawia, że język jest nośnikiem informacji. Tego typu konotacją zajmowały się dziedziny nauki takie jak logika, literatura, socjologia czy psychologia. Te konotacje są chwilowe i zapożyczone na potrzeby danej sytuacji. Odnoszą się do aktualnych wydarzeń i pozwalają na poprawne zidentyfikowanie oraz zinterpretowanie problemu. Zatem oprócz komunikatu i kontekstu ważny jest kod, dzięki któremu rozszyfrowany zostanie przekaz. Informacja, która dostarczana jest w języku powinna być przekazana w sposób najprostszy aby była zrozumiana przez większość odbiorców. Komplikacje w językoznawstwie powstają, kiedy treść i forma przekazu jest niezrozumiała. Jednym z najczęściej występujących utrudnień jest metafora. I choć jest najbardziej podstawowym i uniwersalnym mechanizmem komunikacji to może wpłynąć na uchwycenie sensu. Za najstarsze można przyjąć stanowisko Arystotelesa, który przez termin metafora rozumie przeniesienie nazwy z gatunku na rodzaj, z rodzaju na gatunek, a także przeniesienie nazwy z jakiejś rzeczy na inną przy użyciu analogii, którą tłumaczy jako rodzaj odniesień proporcjonalnych. Pierwotna definicja metafory karze zatem interpretować ją jako zespół słów, w którym znaczenie jednych zostaje niejako przeniesione na znaczenie pozostałych (Głowiński, Okopień-Sławińska, Sławiński 1986: 112).

Reasumując, nauki pomocnicze dla literaturoznawstwa odgrywają bardzo ważną role. Przybliżają tę dziedzinę nauki do aktualnych potrzeb społecznych i przyśpieszają rozwój języka. Każda z nauk pomocniczych wspiera akt komunikacji, w którym język jest nieodłącznym elementem. To przy użyciu nauk pomocniczych w literaturoznawstwie łatwiejsze staje się uchwycenie sensu pojawiających się stwierdzeń zarówno w rzeczywistości, jak i świecie wirtualnym. 


\section{Summary}

Literature is a science that cannot function without auxiliary fields. Their use makes it possible to understand the meaning of difficult expressions, metaphors and neologisms. Ancillary sciences in literature, such as logic, philosophy, sociology, media studies and psychology, bring difficult science closer to ordinary people; making it easier for them to communicate.

\section{Literatura}

Glowiński, M., Okopień-Sławińska M., Slawiński J. Zarys teorii literatury. Warszawa: WSiP 1986.

Podgórni, B. Nauki (od) zawsze stosowane. In: Żabicki, P., Giżycka, E. Promosaurus. Poradnik promocji nauki. Kraków: Centrum Innowacji, Transferu Technologii i Rozwoju Uniwersytetu Uniwersytet Jagieloński, 2013, s. 11-16.

Popper, K. Wiedza obiektywna. Ewolucyjna teoria epistemologiczna. Warszawa: PWN 1992.

Such, J., Szczęśniak, M. Filozofia nauki. Poznań: Wydawnictwo Naukowe UAM, 2006.

Strawiński, W. Funkcje i cele nauki - zarys problematyki metodologicznej. Zagadnienia Naukoznawstwa. 2011 (189/3), s. 323-335.

Woleński, J. Dwa pojęcia nauki: metodologiczne i socjologiczne. Polska Akademia Umiejętności. 2009 (9), s. 163-175.

Rozporządzenie Ministra Nauki i Szkolnictwa Wyższego z dnia 25 września 2018 r., (Dz.U. 2018 poz. 1818). 